\title{
Contents, Vol. 159, 1969
}

\section{Index}

Bacskulin, J.: vide Fhançois, J.

Barishak, R.; Romano, A. and Stein, R.:

Obstruction of Lacrimal Sac Caused by Topical Epinephrine.... 373

Boen-Tan, T. N.: vide Oosterhuis, J. A.

Boeras, F.: vide Voinea, V.

Boest, R. H.: Enzymhistochemische Untersuchungen an der regenerierenden Cornea der Ratte nach Hitzekoagulation des Epithels (Histoenzymatical studies of regenerating cornea of rat after epithelium heat-coagulation) 186

Botez, N.: vide Voinea, V.

Bkambier, A. L.: vide Voinea, V.

Brettschneider, I.:

vide Pbaus, $\mathrm{R}$.

Brienen, J. A. and Snell, C. A. R. D.:

The Mechanism of the Lacrimal Flow

Bucklers, M.: Erblindung bei Masern mit nachfolgender Pigmententartung derNetzhaut (Blindness caused by measles with consequent retinal pigmentary degeneration) 274

Collignon-Brach, J.:

Etude de la biométrie de la cornée au moyen d'une technique photo-graphique (Study of the biometry of the corneal curvature using aphotographic technique) 442

Coppieters, R.: vide Francois, J.

Crousaz, de G.: Symptômes et signes oculaires dans les carences en vitamine B12. Re-marques sur les neuropathies optiques biermériennes (Symptoms andocular lesions in vitamin B12 deficiency. Observations on Biermer'soptic neuropathy) 295

Cuendet, J. F.: vide Sévin, R.

Dreifus, M.: vide Praus, R.

Ducel, G.; Dufour, R.; Sakellaridès, E. et Tanner, F.:

La désinfection des mains en pratique hospitalière ophtalmologique(Hand disinfection in ophthalmic surgery) 407

Dufour, R.: $\quad$ vide Ducel, G.

Faggioni, R.: vide Scouras, J.

Follman, P.; Littmann, J.; Urai, L. and Heszberger, S.:

Ophthalmodynamometry and Ophthalmodynamography in Sub-clavian Steal Syndrome

Francois, J. and Bacskulin, J.:

External Congenital Fistulae of the Lacrimal Sac

Francois, J.; Hanssens, M. et Coppieters, R.:

Rhabdomyosarcome de Гorbite (Rhabdomyosarcoma of the orbit) . 307

Francois, J.; Jònsas, C. and Rouck, de A.: 
Experimental Studies of the Effect of Dithizone on the Electro-Retinogram and the ElectroOculogram in Rabbits 472

Francois, J.; Victoria-Troncoso, V.; Hanssens, M. and Bacskulin, J.:

Scléromalacie perforante et collagénose (Avec une planche en couleur)(Scleromalacia perforans and collagenosis)

71

Giesbrecht, Astréa M.: vide Ramos, L.

Hanssens, M.: vide Francois, J.

Hasselt, van P.: Effects of Optic Nerve Section on the Double-Flash ERG in Un-

anaesthetised Rabbits. A Study of Centrifugal Influences on the ERG 65

Herishanu, Y. and Lavy, S.:

Transient Bilateral Internuclear Ophthalmoplegia of Vascular Origin.

A Case Report 324

Heszberger, S.: vide Follman, P.

Heszberger, I.: vide Radnót, Magda

Ishikawa, S*; Tsukahara, S. and Sato, Y.:

Local Administration of 1\% Ubretid in the Handling of Glaucoma, Myasthenia Gravis and

Esotropia $\quad 339$

Jobbágyi, P.: vide Radnót, Magda

Jönsas, C.: vide Francois, J.

Kani, K.: $\quad$ vide Kurozumi, I.

Köhler, Ursula und Müller, Winfried :

Zur Behandlung von Tränenwegstenosen bei Säuglingen und Kindern (Treatment of lacrymal duct stenosis in infants and children) ... 136

Krause, U. and Raunio, V.:

Proteins of the Normal Human Aqueous Humour 178

Krawsky, G.: La prevention des accidents oculaires. Problèmes psycho-physio-

logiques poses par les lunettes protectrices (Prevention of eye injuries. Psycho-physiological

problems set by protective goggles) . . 152

Kurozumi, I. and Kani, K.:

Electromyograms in the Early Stage of Complete Paralysis of HumanExtraocular Muscles. With Special Reference to the 'FibrillationPotential' and 'Spontaneous Discharge' 233

Kusch, T.: $\quad$ vide Tilgner, $\mathrm{S}$.

Lavy, S.: $\quad$ vide Herishanu, A.

Littmann, J.: vide Follman, P.

Lommatzsch, P. und Voigt, H.:

Über Spätergebnisse der «Cerclage equatorial* nach Arruga (Laterresults of Amiga's 'Cerclage equatorial') 117

Lovas, B.: vide Radnót, Magda

Magora, A.: vide Zauberman, $\mathrm{H}$.

Markwalder, H.: Akutes Schädeltrauma und Gesichtsfeldverlust (Acute cranial trauma

and loss of visual field) 55

Marton, Dezsö v.: Fremdkörper in der Orbita (Foreign bodies in the orbit) 49

Müller, Winfried : vide Köhler, Ursula

Oosterhuis, J. A. and Boen-Tan, T. N.:

Fluorescein Angiography in Papilloedema and Pseudo-Papilloedema 96

Pajic, D.: $\quad$ Ein neuer Trepan für die Keratoplastik und einige Beiträge zur Technik 
der durchgreifenden Hornhaut-Verpflanzung (A new trepan for kerato-plastics and some contributions on extensive corneal transplantation) 389

Pambor, Rosemarie und Thriene, G.:

Retino-Chorioiditis juxtapapillaris (Jensen) (Jensen's retinochoroiditisjuxtapapillaris) 39

Pau, H.: $\quad$ Hyperplasie des Glaskörpergerüstes (Hyperplasia of vitreous body structure) $\quad 166$

Paul, W.: Klinischer Beitrag zum Goldenhar-Syndrom (Clinical contribution

to the Goldenhar-syndrome) 262

Pearce, J. L.: vide Sollom, A. W.

Petrohelos, M. A. and Tricoulis, D.:

Ocular Complications of Chlorpromazine Therapy

Praus, R.; Brettschneider, I. and Dreifus, M.:

Study of the Effect of Hydrophilic Gel Contact Lenses on the Cornea. I. Lactic Acid in the Cornea and Aqueous Humour and Cornea Hydra-tion after Application of Contact Lenses

Geltakt in Rabbits).... 398

Radnót, Magda; Jobbágyi, P.; Heszberger, I. et Lovas, B.:

Les données a Tultrastructure de la rétine humaine sous $\Gamma$ effet de lalumière (Results of ultrastructure of the human retina under exposureto light) $\quad 460$

Ramos, L.; Ramos, A. 0. and Giesbrecht, Astréa M.:

Changes of Intraocular Pressure and of Chloride, Sodium and Potassium Concentrations in Aqueous Humor and Serum of Rabbits Following Ethanol 430

Ramos, A. 0.: vide Ramos, L.

Raunio, V.: vide Krause, U.

Richter, Susanne: Untersuchungen über binokulare Funktionen bei Lähmungsschielen

(Report on binocular visual functions with paralytic strabismus) . . 328

Rivara, A. and Zingirian, M.:

Calculation of Total Refractive Ocular Power and Refractive LensPower: An Ultrasonic Optical Procedure 202

Romano, A.: vide Barishak, R.

Rouck, de A.: vide Francois, J.

Rubinstein, K.: vide Sollom, A. W.

Sakellaridès, E.: vide Ducel, G.

Sato, Y.: $\quad$ vide Ishikawa, S.

Schum, U.: Ultraschalldiagnostik im Glaskörperraum (Ultrasonic diagnosis of vitreous body changes) 239

Scouras, J. and Faggioni, R.:

Ocular Manifestations of Cystinosis

Sévin, R. and Cuendet, J. F.:

Calcium Dobesilate in Diabetic Retinopathy 126

Sharma, O. P.: vide Tomar, V. P. S.

Snell, C. A. R. D.: vide Brienen, J. A.

Sollom, A. W.; Pearce, J. L. and Rubinstein, K.:

Scheie's Operation with Sub-Conjunctival Depomedrone 142

3/8tambuk, V.: vide Zlatar, P.

Stein, R.: $\quad$ vide Barishak, R. 
Tanner, F.: $\quad$ vide Ducel, G.

Thriene, G.: vide Pambor, Rosemarie

Tilgner, S. and Kusch, T.:

U. Untersuchungen über reversible Linsentrübungen bei Ratten undMäusen nach kombinierter Applikation von Phenelzin und Serotonin(Investigations on reversible lens opacities in rats and mice aftercombined application of phenelzin and serotonin) 211 